\title{
LEI COMPLEMENTAR E LEI ORDINÁRIA: OS PROBLEMAS DA HIERARQUIA E DA REVOGAÇÃO
}

\author{
COMPLEMENTARY LAW AND ORDINARY LAW: THE PROBLEMS OF \\ HIERARCHY AND REVOCATION
}

Felipe SCHMIDT ${ }^{1}$

ISSUE DOI: $10.21207 / 1983.4225 .482$

\begin{abstract}
RESUMO
O estudo, elaborado a partir de método dedutivo, versa sobre o problema da existência ou inexistência de hierarquia entre lei complementar e lei ordinária no ordenamento jurídico brasileiro, examinando os posicionamentos doutrinários existentes acerca da matéria (existência de hierarquia, não existência de hierarquia e existência de hierarquia em alguns casos) e sobre a possibilidade ou impossibilidade de esta espécie normativa revogar aquela e vice-versa. Conclui que não há posição prevalecente quanto à hierarquia e que a lei complementar pode ser revogada pela ordinária quando estiver fora de seu campo específico, ao passo que a lei ordinária fora deste é inconstitucional.
\end{abstract}

Palavras-chave: Lei complementar. Lei Ordinária. Hierarquia. Revogação.

\section{ABSTRACT}

The study, based on a deductive method, deals with the problem of the existence or nonexistence of hierarchy between complementary law and ordinary law in the Brazilian legal system, examining the existing doctrinal positions on the subject (existence of hierarchy, no existence of hierarchy and existence of hierarchy in some cases) and on the possibility or impossibility of this normative species

\footnotetext{
${ }^{1}$ Graduado em Direito (UNIVALI/SC); Especialista em Direito do Trabalho (AMATRAXII/SC), Legislação Ambiental e Meio Ambiente (UDESC/SC) e Direito Processual Civil (INCIJUR/SC); Mestrando em Ciência Jurídica pela Universidade do Vale do Itajaí (UNIVALI/SC). Promotor de Justiça de entrância final no Ministério Público do Estado de Santa Catarina (MP/SC). E-mail: fsmafra@gmail.com
} 
to revoke that one and vice versa. It concludes that there is no prevailing position regarding hierarchy and that the supplementary law can be revoked by the ordinary when it is outside its specific field, while the ordinary law outside of it is unconstitutional.

Keywords: Complementary law. Ordinary Law. Hierarchy. Revocation.

\section{INTRODUÇÃO}

O presente estudo versa sobre o problema da existência ou inexistência de hierarquia entre a lei complementar e a lei ordinária no ordenamento jurídico brasileiro e sobre a possibilidade de esta espécie normativa revogar aquela e vice-versa, tendo por objetivo inventariar as diversas concepções doutrinárias surgidas acerca da matéria no país e identificar se ora há uma concepção prevalecente e, em caso positivo, qual seria.

A falta de consenso doutrinário acerca de tais questões, sobre as quais já se debruçaram, ao longo de décadas, diversos estudiosos da Ciência Jurídica no Brasil, entre os quais Ruy Barbosa, Pontes de Miranda, Victor Nunes Leal, Miguel Reale, José Afonso da Silva, Geraldo Ataliba, José Souto Maior Borges, Celso Ribeiro Bastos, Luiz Pinto Ferreira e Manoel Gonçalves Ferreira Filho, tornam oportuno o desenvolvimento desta pesquisa, que está dividida em três partes.

Inicialmente, serão caracterizadas as leis complementares e as leis ordinárias, com o exame dos sentidos formal e material da lei complementar, o delineamento de seu histórico no Direito Constitucional brasileiro, a discussão de seu conceito e natureza jurídica e algumas considerações acerca de leis ordinárias.

Em seguida, será discutido o problema da existência ou não de hierarquia entre a lei complementar e a lei ordinária no sistema jurídicopositivo brasileiro. São três as correntes que procuram solucionar a questão: a primeira sustenta que a hierarquia existe, a segunda que não existe, e a terceira que existe apenas em algumas hipóteses, conforme a espécie de lei complementar considerada.

Ao final, discorre-se sobre a possibilidade de revogação de lei complementar por lei ordinária e sobre o problema inverso, que será apenas superficialmente abordado, por não ter produzido em doutrina controvérsia significativa. 


\section{LEIS COMPLEMENTARES E LEIS ORDINÁRIAS: CARACTERIZAÇÃO}

Para a caracterização das leis complementares e das leis ordinárias serão analisados os conceitos e as naturezas jurídicas dessas duas espécies normativas, bem como realizado breve resgate histórico das leis complementares no Direito brasileiro.

\subsection{OS SENTIDOS DE "LEI COMPLEMENTAR". BREVE HISTÓRICO DO INSTITUTO}

A doutrina pátria toma a expressão "lei complementar" em dois sentidos, um amplo (lato, ontológico, doutrinário, material) e outro estrito (jurídico-positivo, formal).

Em sentido lato, são consideradas leis complementares todas as vetorizadas a completar o texto da Constituição, integrando-lhe e dandolhe aplicabilidade e eficácia ${ }^{2}$, independente de qualquer consideração de forma ou procedimento ${ }^{3}$. É o que sustenta Leal: "em princípio, todas as leis são complementares, porque se destinam a complementar princípios básicos enunciados na Constituição"4 .

Não destoa a lição de Bacha:

A função de complementaridade lato sensu da Constituição, sob o conceito material e doutrinário, é da alçada das leis complementares e ordinárias, pois, consoante melhor doutrina, lei complementar é toda aquela que completa uma norma constitucional não auto-executável ${ }^{5}$.

Em verdade, todos os atos normativos, e não apenas as leis, quer sejam estas complementares ou ordinárias, possuem tal caráter, uma

\footnotetext{
${ }^{2}$ SILVA, José Afonso da. Aplicabilidade das Normas Constitucionais. $3^{\mathrm{a}}$ ed. São Paulo: Malheiros, 1998. p. 235.

${ }^{3}$ BORGES, José Souto Maior. Lei Complementar Tributária. São Paulo: RT: EDUC, 1975. p. 30.

${ }^{4}$ LEAL, Vitor Nunes. Leis Complementares da Constituição. In Revista de Direito Administrativo. Vol. VII, Rio de Janeiro: Forense, 1947. p. 381.

${ }^{5}$ BACHA, Sergio Reginaldo. Constituição Federal. Leis Complementares e Leis Ordinárias. Hierarquia? Belo Horizonte: Fórum, 2004. p. 55.
} 
vez que, direta ou indiretamente, complementam disposições constitucionais ${ }^{6}$ e têm na Constituição seu fundamento de validade.

Contudo, a fim de evitar que se confundam as acepções ampla e restrita da expressão "lei complementar", sugere Silva o uso da expressão "leis integrativas das normas constitucionais" ou "da Constituição" para designar as leis complementares em sentido amplo, classificando-as nas espécies (sentido estrito) "leis complementares da Constituição" (que são examinadas no presente estudo), "leis orgânicas das entidades federativas" (leis orgânicas dos Municípios e do Distrito Federal, sujeitas a quorum especial para aprovação), "leis integrativas orgânicas" (atribuem eficácia e aplicabilidade a normas constitucionais que instituem órgãos menores, determinando sua criação ou ordenando a fixação de sua competência, atribuições e modo de funcionamento) e "leis integrativas sócioideológicas" (integram a eficácia de normas constitucionais de princípio programático, que definem os fins sociais do Estado) ${ }^{7}$.

Destarte, a expressão "lei complementar da Constituição", ou lei complementar em sentido estrito, designaria apenas as leis assim expressamente previstas nas Constituições da República e dos Estados, sujeitas ao regime jurídico nelas definido, pois, conforme Bastos, a lei complementar não tem sua natureza fixada a partir de critérios imanentes, mas é sua relação com a Constituição que lhe define a essência, de modo que a razão de ser daquela se encontra nesta ${ }^{8}$.

Ainda segundo Bastos, o que ensejou a inserção dessa espécie de leis no ordenamento jurídico brasileiro foi a necessidade de conferir maior estabilidade à ordem jurídica ${ }^{9}$, notadamente, conforme Silva, em relação a certas matérias dizentes com o sistema normativo fundamental da Constituição, ou seja, com aqueles princípios vinculados a questões políticas fundamentais ${ }^{10}$, cuja modificação, em face de sua relevância, deveria ser mais dificultosa.

\footnotetext{
${ }^{6}$ CARVAlHO, Paulo de Barros. Curso de Direito Tributário. 16a ed. São Paulo: Saraiva, 2004. p. 204; BASTOS, Celso Ribeiro. Lei Complementar. Teoria e Comentários. São Paulo: Saraiva, 1985. p. 3; FERREIRA, Luiz Pinto. Lei Complementar - I. In Enciclopédia Saraiva do Direito. vol. 48. São Paulo: Saraiva, 1980. p. 495; TEMER, Michel. Elementos de Direito Constitucional. $15^{\mathrm{a}}$ ed. São Paulo: Malheiros, 1999. p. 147.

${ }^{7}$ SILVA, José Afonso da. Aplicabilidade das Normas Constitucionais, p. 240.

${ }^{8}$ BASTOS, Celso Ribeiro. Lei Complementar. Teoria e Comentários. $2^{\mathrm{a}}$ ed. São Paulo: Celso Bastos Editor, Instituto Brasileiro de Direito Constitucional, 1999. p. 24.

${ }^{9}$ BASTOS, Celso Ribeiro. Op. cit., p. 41.

${ }^{10}$ SILVA, José Afonso da. Op. cit., p. 243.
} 
Todavia, a lei complementar tem raízes europeias, que se situam nas lois organiques (leis orgânicas) do direito francês, tendo sido prevista inicialmente na Constituição Francesa de 1848 (art. 115) e reproduzida na vigente Constituição Francesa de 1958 (art. 46), que lhe traçou o perfil atual, de ato legislativo que possui processo de elaboração mais dificultoso que o das leis ordinárias ${ }^{11 .}$

Na linha do Direito francês, tal espécie normativa ingressou no Direito nacional sob a denominação de "lei orgânica", introduzida pela Constituição de $1891^{12}$, tendo sido prevista, com a mesma nomenclatura, também na Constituição de $1934^{13}$.

Nas Constituições de 1937 e 1946, não foi disciplinada a lei orgânica, reintroduzida no Direito Positivo brasileiro, já sob a denominação de lei complementar, pela Emenda Constitucional no 04, de 02 de setembro de $1961^{14}$, que inaugurou a previsão de exigência do quorum qualificado de maioria absoluta para sua elaboração, tendo sido revogada pela Emenda Constitucional $n^{\circ}$ 06, de 23 de janeiro de $1963^{15}$.

Contudo, na Emenda Constitucional $n^{\circ} 17$, de 26 de novembro de $1965^{16}$, foi retomada a expressão "leis complementares", posteriormente reproduzida e consolidada na Emenda Constitucional $n^{\circ} 18$, de $1^{\circ}$ de dezembro de $1965^{17}$.

\footnotetext{
${ }^{11}$ BASTOS, Celso Ribeiro. Lei Complementar. Teoria e Comentários. $2^{\mathrm{a}}$ ed., p. 29.

12 “Art. 34 - Compete privativamente ao Congresso Nacional: (...); 33. decretar as leis e resoluções necessárias ao exercício dos poderes que pertencem á União; 34. decretar as leis orgânicas para a execução completa da Constituição".

13 “Art. 39 - Compete privativamente ao Poder Legislativo, com a sanção do Presidente da República: 1) decretar leis orgânicas para a completa execução da Constituição; (...)".

14 "Art. 22. Poder-se-á complementar a organização do sistema parlamentar de Governo ora instituído, mediante leis votadas, nas duas Casas do Congresso Nacional, pela maioria absoluta de seus membros".

15 "Art. $1^{\circ}$ Fica revogada a Emenda Constitucional n 4 (...)".

16 "Art. $6^{\circ}$ Os parágrafos do art. 67 da Constituição passam a ter a seguinte redação: (...) $§ 8^{\circ}$ Os projetos de leis complementares da Constituição e os de Código ou de reforma de Código receberão emendas perante as comissões, e sua tramitação obedecerá aos prazos que forem estabelecidos nos regimentos internos ou em resoluções especiais".

${ }^{17 " A r t .} 1^{\circ} \mathrm{O}$ sistema tributário nacional compõe-se de impostos, taxas e contribuições de melhoria, e é regido pelo disposto nesta Emenda, em leis complementares, em resoluções do Senado Federal, e, nos limites das respectivas competências, em leis federal, estadual ou municipal". "Art. $2^{\circ}$. E vedado à União, aos Estados, ao Distrito Federal e aos Municípios: (...) IV - cobrar impostos sobre: (...) c) o patrimônio, a renda ou os serviços de partidos políticos e de instituições de educação ou de assistência social, observados os requisitos fixados em lei complementar". "Art. $4^{\circ}$. Somente a União, em casos excepcionais definidos em lei complementar, poderá instituir empréstimos compulsórios". "Art.
} 
Assim, a partir das Emendas Constitucionais n ${ }^{\circ} 17$ e 18 à Constituição de 1946, as leis complementares caminharam para se tornar espécies normativas autônomas, distintas das demais, no ordenamento jurídico brasileiro.

Foi a Constituição de 1967 que consagrou expressamente a autonomia normativa da lei complementar (art. 49, II), seguida pela Emenda Constitucional n 01/1969 (art. 46, II) e pela Constituição de 1988 (art. 59 , II) na forma que segue:

Art. 59. O processo legislativo compreende a elaboração de:

I - emendas à Constituição;

II - leis complementares;

III - leis ordinárias;

IV - leis delegadas;

$\mathrm{V}$ - medidas provisórias;

VI - decretos legislativos;

VII - resoluções.

Parágrafo único. Lei complementar disporá sobre a elaboração, redação, alteração e consolidação das leis.

À vista do acolhimento da expressão "lei complementar" pelo Direito Positivo pátrio, só se admite como lei complementar, ao menos do ponto de vista técnico, aquela expressamente prevista na Constituição. Tomou-se impróprio, por conseguinte, intitular "lei complementar" qualquer norma destinada a integrar a Constituição que nela não esteja prevista como tal ${ }^{18}$. Destarte, assiste razão a Silva ao propor denominar "leis integrativas das normas constitucionais" ou "da Constituição" as leis complementares em sentido amplo, vale dizer, aquelas assim não denominadas no texto constitucional.

12. Compete aos Estados o imposto sobre operações relativas à circulação de mercadorias, realizadas por comerciantes, industriais e produtores. $\S 1^{\circ} \mathrm{A}$ alíquota do imposto é uniforme para todas as mercadorias, não excedendo, nas operações que as destinem a outro Estado, o limite fixado em resolução do Senado Federal, nos termos do disposto em lei complementar". "Art. 15. Compete aos Municípios o imposto sobre serviços de qualquer natureza, não compreendidos na competência tributária da União e dos Estados. Parágrafo único. Lei complementar estabelecerá critérios para distinguir as atividades a que se refere este artigo das previstas no art. 12".

${ }^{18}$ BASTOS, Celso Ribeiro. Lei Complementar. Teoria e Comentários. p. 16. 
Definidas as acepções doutrinárias da expressão "lei complementar" e traçado um breve escorço histórico do instituto notadamente no Direito Constitucional brasileiro, importa fixar seu conceito jurídico-positivo e sua natureza jurídica.

\subsection{CONCEITO E NATUREZA JURÍDICA DA LEI COMPLEMENTAR}

Para Sarasate, citado por Ferreira, leis complementares são:

aquelas que, aprovadas no mínimo pela maioria absoluta dos membros das duas casas do Congresso Nacional, e observados, na sua elaboração, os demais termos de votação das leis ordinárias, têm por objetivo regular os preceitos constitucionais cuja aplicação delas depende expressamente ${ }^{19}$.

Veja-se a lição de Ataliba:

o conceito jurídico-positivo depende do sistema, tal como formalmente erigido e disposto pelo legislador - no caso - constituinte. É lei complementar - de acordo com o conceito jurídico-positivo - aquela expressamente prevista pelo texto constitucional e para cuja elaboração se previu processo especial e qualificado. Especial porque exclusivo e próprio da espécie; qualificado porque revestido de exigências que o tornam qualitativamente superior ao próprio das leis ordinárias $^{20}$.

Tais definições, no dizer de Borges, pecam por generalizar, sem exceção, a regra da expressa previsão constitucional como requisito para identificar hipótese de exigência de lei complementar ${ }^{21}$.

Segundo Silva, "leis complementares da Constituição são leis integrativas de normas constitucionais de eficácia limitada, contendo

\footnotetext{
${ }^{19}$ SARASATE, Paulo. A Constituição ao Alcance de Todos. Rio de Janeiro, 1963, p. 333, apud FERREIRA, Luiz Pinto. Lei Complementar - I. In Enciclopédia Saraiva do Direito. p. 496.

${ }^{20}$ ATALIBA, Geraldo. Lei Complementar na Constituição. São Paulo: RT, 1971. p. 30.

${ }^{21}$ BORGES, José Souto Maior. Lei Complementar Tributária. p. 32.
} 
princípio institutivo ou de criação de órgãos e sujeitas à aprovação pela maioria absoluta dos membros das duas Casas do Congresso Nacional"22.

Bastos entende ser a lei complementar,

espécie normativa autônoma, expressamente prevista no inciso II do art. 46 da Constituição Federal [Emenda Constitucional $\mathrm{n}^{\circ}$ 1, de 1969], que versa sobre matéria subtraída ao campo de atuação das demais espécies normativas do nosso direito positivo, demandando, para a sua aprovação, um quorum especial de maioria absoluta dos votos dos membros das duas Casas que compõem o Congresso Nacional ${ }^{23}$.

Para Carvalho, "lei complementar é aquela que, dispondo sobre matéria, expressa ou implicitamente, prevista na redação constitucional, está submetida ao quorum qualificado do art. 69 (CF), isto é, maioria absoluta nas duas Casas do Congresso Nacional"24.

Pode-se concluir, do exame dos conceitos doutrinários acima transladados, que, sob o aspecto jurídico-positivo, em síntese: 1) leis complementares são as aprovadas, no mínimo, pela maioria absoluta dos membros das duas Casas do Congresso Nacional e 2) destinadas a versar sobre as matérias expressamente previstas no texto constitucional.

O quorum para aprovação das leis complementares é especial, distinto do das leis ordinárias. Aquelas se aprovam por maioria absoluta (art. 69 da Constituição da República) e estas por maioria simples (art. 47 da Constituição da República) ${ }^{25}$. Segundo Bastos, "só existe lei complementar porque a Constituição prevê uma forma especial pela qual podem ser veiculadas certas matérias. Abolida a exigência da maioria absoluta dos votos, a lei complementar passa a se confundir com a figura da lei ordinária" 26.

Acerca do quorum da lei complementar e da lei ordinária, lecionam Paulo e Alexandrino:

\footnotetext{
${ }^{22}$ SILVA, José Afonso da. Aplicabilidade das Normas Constitucionais. p. 244.

${ }^{23}$ BASTOS, Celso Ribeiro. Lei Complementar. Teoria e Comentários. p. 17.

${ }^{24}$ CARVALHO, Paulo de Barros. Curso de Direito Tributário. p. 205.

${ }^{25}$ TEMER, Michel. Elementos de Direito Constitucional. p. 147.

${ }^{26}$ BASTOS, Celso Ribeiro. Do Processo Legislativo da Lei Complementar. In: Revista de Direito Constitucional e Internacional, ${ }^{\circ}$ 38. São Paulo: RT, 2002. p. 97.
} 
É certo que o legislador constituinte outorgou à lei complementar uma relativa rigidez, ao exigir para sua aprovação maioria absoluta dos membros das duas Casas do Congresso Nacional. Atualmente, considerando a composição das Casas do Congresso Nacional (Câmara com 513 Deputados; Senado com 81 Senadores), para a aprovação de uma lei complementar é necessário o voto favorável de 257 Deputados e de 41 Senadores, independentemente do número de congressistas presentes à sessão.

A aprovação das leis ordinárias é bem mais simples, pois depende apenas da chamada maioria simples ou relativa, isto é, exige a maioria dos votos dos parlamentares presentes, desde que esteja presente na sessão a maioria absoluta dos membros da Casa Legislativa. Logo, o quorum de maioria simples é um número variável, dependendo do número de parlamentares presentes à sessão ${ }^{27}$.

Nas palavras de Reale, as leis complementares são "um tertium genus de leis, que não ostentam a rigidez dos preceitos constitucionais, nem tampouco devem comportar revogação (perda de vigência) por força de qualquer lei ordinária superveniente"28.

Ressalte-se neste ponto, por oportuno, que, conforme a doutrina, a lei complementar "apresenta o mesmo processo legislativo das leis ordinárias, com exceção do quorum" ${ }^{29}$. Assim, para as leis complementares, são observados todos os demais termos da tramitação das leis ordinárias, como estabelecido na Constituição. A Emenda Constitucional $n^{\circ}$ 01/1969, aliás, dispunha expressamente que "a lei complementar há de ser votada observados os demais termos de votação das leis ordinárias, pela maioria absoluta dos membros das duas Casas do Congresso" ${ }^{\prime 30}$. Embora não reproduzido tal preceito na Constituição de 1988, é de se entender que seu conteúdo continua aplicável.

\footnotetext{
${ }^{27}$ PAULO, Vicente; ALEXANDRINO, Marcelo. Processo Legislativo. Niterói: Impetus, 2003. p. 197.

${ }^{28}$ REALE, Miguel. Parlamentarismo Brasileiro. São Paulo: Saraiva, 1962, p. 110 apud MORAES, Alexandre de. Direito Constitucional. $28^{\mathrm{a}}$ ed. São Paulo: Saraiva, 2012. p. 697.

${ }^{29}$ ARAÚJO, Luiz Alberto David; NUNES JR. Vidal Serrano. Curso de Direito Constitucional. São Paulo: Saraiva, 1998. p. 261.

${ }^{30}$ FERREIRA FILHO, Manoel Gonçalves. Lei Complementar - II. In: Enciclopédia Saraiva de Direito, v. 48. São Paulo: Saraiva, 1980. p. 514.
} 
O âmbito material das leis complementares é taxativo e previsto na Constituição de modo expresso ${ }^{31}$. Assim, "à lei complementar compete tão-só disciplinar a matéria expressamente a ela reservada por dispositivo constitucional"32.

Quanto ao ponto, colhe-se da lição de Paulo e Alexandrino:

Com efeito, caso o Congresso Nacional (ou as outras Casas Legislativas) pudesse, a seu arbítrio, regular por meio de lei complementar matérias não reservadas a essa espécie normativa e, assim fazendo, impossibilitasse que a disciplina dessa matéria, no futuro, fosse modificada por lei ordinária, teria ele o poder de engessar as futuras legislaturas, tornando indevidamente dificultosa a disciplina de matéria para a qual o constituinte não previu necessidade de aprovação por maioria absoluta. Como consequência, o Congresso Nacional teria a possibilidade de, sempre que desejasse, substituir pela sua a vontade do constituinte originário, tornando necessária lei complementar para regulamentar matérias para as quais o constituinte somente exigiu lei ordinária33.

Controvertida na doutrina é a natureza jurídica das leis complementares: há quem as considere leis intercalares (Pontes de Miranda), leis ordinárias paraconstitucionais (Miguel Reale) e leis de hierarquia intermediária (Georges Burdeau). Para Silva, entretanto, as leis complementares terão a natureza jurídica que seu conteúdo indicar ${ }^{34}$.

À vista das diversas manifestações doutrinárias referentes à natureza jurídica da lei complementar, Bacha conclui o seguinte:

na doutrina houve uma evolução quanto às concepções acerca da natureza jurídica da lei complementar: de um texto constitucional cuja previsão é lacônica e obscura, a ser um tertium genus de lei, leis or-

\footnotetext{
${ }^{31}$ BACHA, Sergio Reginaldo. Constituição Federal. Leis Complementares e Leis Ordinárias. Hierarquia? p. 42; MALUF, Sahid. Direito Constitucional. 19a ed. São Paulo: Sugestões Literárias, 1988. p. 226.;GUERRA, Sidney; MERÇON, Gustavo. Direito Constitucional Aplicado à Função Legislativa. Rio de Janeiro: América Jurídica, 2002. p. 228.

${ }^{32}$ SILVA, José Afonso da. Aplicabilidade das Normas Constitucionais. p. 248.

${ }^{33}$ PAULO, Vicente; ALEXANDRINO, Marcelo. Processo Legislativo. p. 199/200.

${ }^{34}$ SILVA, José Afonso da. Aplicabilidade das Normas Constitucionais. p. 243.
} 
dinárias paraconstitucionais, para ser lei de categoria intercalar, passando pela intolerância do meio termo a categoria científica autônoma, de natureza clara, a uma concepção de que será a Constituição que lhe definirá a essência ${ }^{35}$.

O autor sintetiza corretamente os diversos posicionamentos respeitantes à natureza jurídica da espécie legislativa sob exame, porém, impõe-se reconhecer, sem pôr fỉm à celeuma doutrinária acerca da questão.

\subsection{LEI ORDINÁRIA: CARACTERIZAÇÃO}

Cabe ainda caracterizar a espécie normativa "lei ordinária", a fim de que se possa enfrentar, de modo adequado, a matéria referente à existência ou inexistência de hierarquia entre leis complementares e ordinárias e à possibilidade ou impossibilidade de revogação daquelas por estas.

A lei ordinária, segundo a doutrina, é a espécie normativa padrão, típica, geral ou comum e abstrata ${ }^{36}$, existente na ordem jurídica pátria desde antes da Constituição de $1824^{37}$.

É padrão, porque toda lei a ser editada é ordinária, salvo quando a Constituição, expressa e excepcionalmente, exige o contrário; típica, porque expressamente prevista no art. 59, III, da Constituição da República; geral, ou comum, pois se dirige a todos indistintamente, dentro de seu campo de aplicação, e abstrata, porque apartada das circunstâncias diversas e variáveis que se apresentam em cada caso concreto ${ }^{38}$. Contudo, cabe reconhecer que tais características são também perfeitamente aplicáveis às leis complementares, à exceção da primeira delas.

\footnotetext{
${ }^{35}$ BACHA, Sergio Reginaldo. Constituição Federal. Leis Complementares e Leis Ordinárias. Hierarquia? p. 37.

${ }^{36}$ GUERRA, Sidney; MERÇON, Gustavo. Direito Constitucional Aplicado à Função Legislativa. p. 229.

${ }^{37}$ Por exemplo: "Lei - de 20 de outubro de 1823. Estabelece provisoriamente a forma que deve ser observada na promulgação dos Decretos da Assembleia Geral Constituinte e Legislativa do Brasil". Disponível em: <http://www.camaragov.br/Internet/InfDoc/conteudo/colecoes/Legislacao/LegimpF_8O.pdf $>$.

${ }^{38}$ MONTORO, Franco. Introdução à Ciência do Direito, p. 329.
} 
Pontes de Miranda concebia as leis ordinárias da seguinte for-

ma:

são as leis editadas pelo Congresso Nacional, sem que se insiram na Constituição, ou se juntem à Constituição, sem que a complementem e sem provirem de delegação ou de decreto-lei, e sem consistirem em simples 'resolução'. O conceito diminuiu de conteúdo com a Constituição de 1967, porque, em sentido próprio, lei ordinária é lei que não é constitucional ${ }^{39}$.

O autor destaca a autonomia da lei ordinária, distinguindo-a das demais espécies normativas previstas pela Emenda Constitucional $\mathrm{n}^{\circ}$ 01/1969 à Constituição de 1967; sustenta que a lei ordinária não se presta para complementar a Constituição, função exercida especificamente pelas leis complementares em sentido estrito, e aduz que a Carta Magna acabou por reduzir seu conceito, seja por não se integrar à Constituição, seja por ter esta albergado outra espécie normativa (qual seja, a lei complementar) especificamente para complementá-la.

Assim, são distintas as leis complementares e ordinárias no Direito Positivo nacional. Os critérios diferenciadores das duas espécies normativas são aqueles definidos na Constituição, quais sejam, os campos materiais próprios e o quorum para aprovação ${ }^{40}$.

Lei ordinária tem campo material residual definido por exclusão, de modo que, nas hipóteses em que a Constituição não exige expressamente lei complementar, decreto legislativo ou resolução, é admissível que lei ordinária regule a matéria ${ }^{41}$.

A doutrina aponta diversas situações em que se admite a edição de lei ordinária, entre as quais as seguintes:

\footnotetext{
${ }^{39}$ PONTES DE MIRANDA. Comentários à Constituição de 1967 com a Emenda nº 01 de 1969 apud BACHA, Sergio Reginaldo. Constituição Federal. Leis Complementares e Leis Ordinárias. Hierarquia? p. 51.

${ }^{40}$ BACHA, Sergio Reginaldo. Constituição Federal. Leis Complementares e Leis Ordinárias. Hierarquia? p. 59.

${ }^{41}$ TEMER. Michel. Elementos de Direito Constitucional, p. 148; BACHA, Sergio Reginaldo. Constituição Federal. Leis Complementares e Leis Ordinárias. Hierarquia? p. 59; GUERRA, Sidney; MERÇON, Gustavo. Direito Constitucional Aplicado à Função Legislativa, p. 230; GONÇALVES, Fernanda Bernardo. O processo legislativo na Constituição brasileira de 1988. In: CLÈVE, Clemerson Merlin (coord.). Direito Constitucional Brasileiro. Vol. 2. Organização do Estado e dos Poderes. São Paulo: RT, 2014. p. 390.
} 
1) a Constituição prevê a matéria e determina expressamente sua regulamentação por meio de Lei Ordinária; 2) a Constituição prevê a matéria e utiliza o termo "lei" para indicar a espécie normativa que irá regulamentá-la; 3) a Constituição prevê a matéria mas não indica qual a espécie normativa que irá regulamentá-la; 4) a Constituição é omissa quanto à matéria, porém sua regulamentação também será via Lei Ordinária ${ }^{42}$.

No que toca ao processo legislativo, cumpre repisar que a lei ordinária e a complementar têm tramitação idêntica, ressalvado o quorum para aprovação, que na lei ordinária é a maioria simples (art. 47 da Constituição da República) e na lei complementar, como visto, é a maioria absoluta (art. 69 da Constituição da República).

\section{LEIS COMPLEMENTARES E LEIS ORDINÁRIAS: 0 PROBLEMA DA HIERARQUIA}

Definidas, ainda que em linhas gerais, as características essenciais das leis complementares e ordinárias, passar-se-á ao exame do problema referente à existência ou não de hierarquia entre tais espécies normativas.

Cumpre destacar, logo de início, que a noção ampla de lei complementar, conforme José Souto Maior Borges, não se presta para fundamentar qualquer consideração sobre sua hierarquia e eficácia no ordenamento jurídico brasileiro, vez que o que aparta as espécies normativas em distintos níveis hierárquicos não são aspectos materiais (vale dizer, a matéria regulada por cada uma das espécies), mas aspectos formais, técnicos (ou seja, a unidade de características atribuídas pelo constituinte a dado conjunto de normas) $)^{43}$.

Hugo de Brito Machado acata tal posicionamento: "toda e qualquer espécie normativa ganha identidade específica, e assim tem definida

\footnotetext{
${ }^{42}$ GUERRA, Sidney; MERÇON, Gustavo. Direito Constitucional Aplicado à Função Legislativa. p. 230.

${ }^{43}$ BORGES, José Souto Maior. Lei Complementar Tributária. p 32.
} 
a sua posição hierárquica no sistema jurídico, a partir de elementos formais. Não em razão de seu conteúdo"44.

Portanto, é oportuno ressaltar de plano que, para fins de desenvolvimento da problemática atinente à existência ou inexistência de hierarquia entre a lei complementar e a lei ordinária no sistema jurídicopositivo brasileiro, tomar-se-á em conta somente a noção formal de lei complementar, tal como delineada no capítulo anterior.

Outrossim, há que se ter em conta que a ideia de hierarquia pressupõe a existência de campo material comum entre os atos normativos, vale dizer, que o ato subordinante limita a área material de disposição do ato subordinado ${ }^{45}$.

Impõe-se, ademais, caracterizar, em sentido jurídico, hierarquia.

Por hierarquia, consoante Michel Temer, entende-se "a circunstância de uma norma encontrar sua nascente, sua fonte geradora, seu ser, seu engate lógico, seu fundamento de validade, numa norma superior" ${ }^{46}$.

Celso Ribeiro Bastos acrescenta o que segue:

A hierarquia é um dos recursos de que se vale o sistema jurídico para resolver os conflitos lógicos que suas proposições normativas encerrem. (...) A hierarquia é uma das alavancas que promovem tal operação. As outras são a determinação de que a lei posterior revoga a anterior e a reserva de matérias a determinada sorte de atos jurídicos ${ }^{47}$.

Conforme Celso Bastos, J. J. Gomes Canotilho justifica o princípio da hierarquia em razão da pluralidade das normas e da função ordenadora do Direito ${ }^{48}$.

Segundo José Souto Maior Borges "o termo 'hierarquia' só tem sentido juridicamente para significar que uma norma é inferior a outra norma quando a segunda regule a forma de criação da primeira norma"49.

\footnotetext{
${ }^{44}$ MACHADO, Hugo de Brito. Curso de Direito Tributário. 19a ed. São Paulo: Malheiros, 2001. p. 67.

${ }^{45}$ BASTOS, Celso Ribeiro. Lei Complementar. Teoria e Comentários. 2a ed. p. 66.

${ }^{46}$ TEMER, Michel. Elementos de Direito Constitucional. p. 146.

${ }^{47}$ BASTOS. Celso Ribeiro. Op. cit., p. 25.

${ }^{48}$ Idem, p. 65.

${ }^{49}$ BORGES, José Souto Maior. Lei Complementar Tributária. p. 56.
} 
Caracterizada essa categoria, fundamental para o exame do tema proposto, cabe apontar que se vislumbram três posicionamentos distintos acerca do problema: alguns estudiosos defendem a existência de hierarquia entre lei complementar e lei ordinária, atribuindo superioridade àquela, outros sustentam que inexiste tal superioridade, estando, por conseguinte, ambas as espécies normativas no mesmo plano hierárquico no ordenamento jurídico pátrio, sem qualquer subordinação de uma à outra, e outros ainda defendem posição intermediária, sustentando a existência de tal hierarquia em algumas hipóteses apenas, como se verá a seguir.

\subsection{A EXISTÊNCIA DE HIERARQUIA ENTRE LEI COMPLEMENTAR E LEI ORDINÁRIA}

Consoante Borges, os critérios que fundamentam a defesa da existência de hierarquia entre lei complementar e lei ordinária são os que seguem $^{50}$ :

1. As leis complementares se situam logo abaixo das emendas à Constituição e acima das leis ordinárias, no art. 49 da Constituição de 1967, art. 46 da Emenda Constitucional $n^{\circ} 1$ de 1969 e art. 59 da Constituição de 1988 ;

2. A lei ordinária não pode alterar a lei complementar ou revogá-la;

3. O quorum especial e qualificado estabelecido para a aprovação da lei complementar lhe confere superioridade formal ou eficacial à lei ordinária.

Destaque-se que o aspecto constante do ponto 2 será objeto de exame em passagem posterior do presente estudo, versante sobre o problema da possibilidade ou não de revogação da lei complementar pela lei ordinária. Proceder-se-á, por ora, à análise dos pontos 1 e 3 .

Ao examinar o art. 59 da vigente Constituição da República, transcrito no capítulo precedente deste estudo, vê-se que as leis complementares (inciso II), estão posicionadas abaixo das emendas à Constitui-

${ }^{50}$ Idem, p. 19. 
ção (inciso I) e acima das leis ordinárias (inciso III). Situação semelhante verificou-se no art. 49 da Constituição de 1967 e no art. 46 da Emenda Constitucional $\mathrm{n}^{\circ} 1 / 69$.

Em face dessa posição da lei complementar no rol de espécies normativas na Constituição, interpretou Geraldo Ataliba:

é próprio da técnica de elaboração legislativa inserir os mandamentos eventualmente hierarquizados em ordem tal que os superiores precedam os inferiores e vice-versa. Assim, as enumerações em regra começam pelo mais relevante ou importante, em ordem decrescente" 51 .

Destarte, as leis complementares ocupariam posição superior às leis ordinárias na estrutura escalonada do ordenamento jurídico brasileiro, por estarem previstas no inciso II do art. 59 da Constituição de 1988, ao passo que estas estariam, logicamente, em posição inferior àquelas, por se situarem no inciso III do mesmo dispositivo.

À vista de tal modo de enumeração das espécies normativas, e na esteira do entendimento de Geraldo Ataliba, parcela da doutrina considerou que haveria hierarquia entre leis complementares e leis ordinárias.

Para Luiz Pinto Ferreira, por exemplo, "a lei complementar ocupa uma posição intercalar e intermediária no ordenamento jurídico. Vale menos que a lei constitucional, vale mais que a lei ordinária"52.

Conforme Cretella Júnior, "numa disposição hierárquica ou escalonada das regras jurídicas legais, diríamos que a lei complementar representa um plus, em relação à lei ordinária, e um minus, em relação à emenda constitucional" ${ }^{53}$.

Consoante Maluf, "as leis complementares colocam-se hierarquicamente acima das leis ordinárias" 54 .

Ferreira Filho sustenta que "a lei complementar é um tertium genus interposto, na hierarquia dos atos normativos, entre a lei ordinária

\footnotetext{
${ }^{51}$ ATALIBA, Geraldo. Lei Complementar na Constituição. p. 29.

${ }^{52}$ FERREIRA, Luiz Pinto. Lei Complementar - I. In Enciclopédia Saraiva de Direito. p. 497.

${ }^{53}$ CRETELLA JR. José. Elementos de Direito Constitucional. $3^{\mathrm{a}}$ ed. São Paulo: RT, 2000. p. 192.

${ }^{54}$ MALUF, Sahid. Direito Constitucional. p. 226.
} 
(e os atos que têm a mesma força que esta - a lei delegada e o decreto-lei) e a Constituição (e suas emendas)" 55 .

Para Silva, "na Constituição vigente, as leis complementares adquirem superioridade formal relativamente às outras leis, num status intermédio entre leis constitucionais e leis ordinárias"56.

Por fim, Bacha aduz:

a questão da topografia do dispositivo das leis complementares, ab initio, na Constituição de 1967/69 (art. 46, inciso II), depois na Constituição de 1988 (art. 59, inciso II), não deixa dúvidas quanto ao caráter de primazia desta espécie normativa. Acaso os legisladores constituintes não quisessem deliberadamente consignar este grau de precedência como indicador de importância, teriam alocado então as leis ordinárias (inciso III) no mesmo patamar das leis complementares, ficando, in casu, ambas as espécies normativas inscritas no inciso II, tendo acima delas e no inciso I apenas as emendas à Constituição, dentro dos artigos correspondentes ao processo legislati$\mathrm{vo}^{57}$.

Tal posicionamento, apesar de defendido por numerosos e renomados juristas, não é pacífico na doutrina, como se verificará abaixo.

O outro ponto, de $n^{\circ} 3$, que fundamenta a argumentação favorável à supremacia formal da lei complementar sobre a lei ordinária, diz respeito ao quorum especial e qualificado estabelecido pela Constituição da República para a aprovação da lei complementar.

Borges resume o posicionamento dos diversos estudiosos que defendem a existência de hierarquia com fulcro no quorum diferenciado de aprovação da lei complementar:

pretende a doutrina identificar no quorum especial e qualificado, constitucionalmente previsto para a aprovação da lei complementar, uma característica

\footnotetext{
${ }^{55}$ FERREIRA FILHO, Manoel Gonçalves. Lei Complementar - II. In Enciclopédia Saraiva de Direito. p. 513.

${ }^{56}$ SILVA, José Afonso da. Aplicabilidade das Normas Constitucionais, p. 234.

${ }^{57}$ BACHA, Sergio Reginaldo. Constituição Federal. Leis Complementares e Leis Ordinárias. Hierarquia? p. 105.
} 
de eficácia que lhe conferiria superioridade formal com relação a outros atos legislativos, numa posição intermediária entre a Constituição e as leis ordinárias58.

De fato, prevê o art. 69 da Constituição da República que "as leis complementares serão aprovadas por maioria absoluta".

Deste dispositivo, correspondente ao art. 50 da Emenda Constitucional $n^{\circ} 01 / 1969$, extrai-se o regime jurídico especial da lei complementar, caracterizado pelo quorum qualificado para sua elaboração (maioria absoluta de votos em cada uma das Casas do Congresso Nacional).

A lei ordinária, assim, ocuparia posição hierárquica inferior à da lei complementar, por depender apenas de maioria simples de votos nas duas Casas do Congresso para ser aprovada, conforme dispõe o art. 47 da Constituição de 1988: "salvo disposição constitucional em contrário, as deliberações de cada Casa e de suas Comissões serão tomadas por maioria dos votos, presente a maioria absoluta de seus membros".

Assim, segundo Ferreira, "formalmente, as leis complementares são superiores às leis ordinárias. Logo depois das leis constitucionais situam-se elas numa escala intermediária, porém acima das leis ordinárias" ${ }^{2}$.

Silva, na mesma linha, sustenta que a rigidez das leis complementares é menor que a das emendas constitucionais e maior que a das leis ordinárias, uma vez que o processo de formação das emendas constitucionais exige outros requisitos que não são previstos para as leis complementares, e "estas só se diferenciam das leis ordinárias no tocante ao quorum para sua aprovação no Congresso"60.

Para Sarasate, a Constituição de República estabelece para as leis complementares "um quorum especial de votação - maioria absoluta conferindo-lhes destarte aquela característica formal a que aludimos e que lhes dá uma posição hierárquica inequívoca, logo abaixo das emendas constitucionais, na dinâmica legislativa"61, e, cabe acrescentar, prosseguindo seu raciocínio, logo acima das leis ordinárias.

\footnotetext{
${ }^{58}$ BORGES, José Souto Maior. Lei Complementar Tributária. p. 36.

${ }^{59}$ FERREIRA, Luiz Pinto. Lei Complementar - I. In Enciclopédia Saraiva de Direito. p. 498.

${ }^{60}$ SILVA, José Afonso da. Aplicabilidade das Normas Constitucionais. p. 246.

${ }^{61}$ SARASATE, Paulo. A Constituição ao Alcance de Todos, p. 33, apud BACHA, Sergio Reginaldo. Constituição Federal. Leis Complementares e Leis Ordinárias. Hierarquia? p. 107.
} 
Esses, em suma, os posicionamentos doutrinários que sustentam a existência de hierarquia entre lei complementar e lei ordinária, conferindo primazia àquela.

\subsection{A INEXISTÊNCIA DE HIERARQUIA ENTRE LEI COMPLEMENTAR E LEI ORDINÁRIA}

Outros estudiosos procuraram refutar a argumentação favorável à existência de hierarquia entre a lei complementar e a lei ordinária.

Contesta Borges "que, dessa 'inserção sistemática' da lei complementar, se deva concluir por sua superioridade no confronto com a lei ordinária. Da posição intermediária que, no rol do art. 46 da Constituição [de 1967] ocupa a lei complementar não se segue que a lei ordinária retire necessariamente sua validade da conformidade com ela"62.

Surge aí o problema do fundamento de validade da norma jurídica.

Segundo Kelsen, "uma norma que representa o fundamento de validade de uma outra norma é figurativamente designada como norma superior, por confronto com uma norma que é, em relação a ela, norma inferior"63.

Assim, norma superior em hierarquia é a que dá fundamento de validade a outra, que lhe é hierarquicamente inferior. E lhe dá fundamento de validade porque determina o modo de sua criação, de sorte que a norma criada em conformidade com outra lhe é inferior e a norma que define a forma de produção desta última lhe é superior.

É o que expõe Borges:

A relação de hierarquia supõe que uma norma retira sua validez de conformidade com outra norma. A segunda norma constitui a razão de validez da primeira porque determina sua criação. Diz-se então que a primeira é una norma subordinada ou de grau inferior e, a segunda, uma norma subordinante ou de grau superior. A relação entre a norma subordinante

\footnotetext{
${ }^{62}$ BORGES, José Souto Maior. Lei Complementar Tributária. p. 21.

${ }^{63}$ KELSEN, Hans. Teoria Pura do Direito. $6^{\mathrm{a}}$ ed. Tradução de João Baptista dos Santos. São Paulo: Martins Fontes, 1998. p. 215.
} 
e a norma subordinada, cuja criação é regulada pela norma subordinante, é uma relação de hierarquia, consistente num vínculo de supra e subordinação. A norma que determina a criação de outra norma lhe é superior ou supra-ordenada; a criada em conformidade dela, inferior ou subordinada, Essas normas, portanto, não guardam entre si uma relação de coordenação, mas de subordinação hierárquica64.

À vista de tal argumentação, cumpre examinar o que indaga Michel Temer: "lei ordinária, por acaso, encontra seu fundamento de validade, seu engate lógico, sua razão de ser, sua fonte geradora, na lei complementar? Absolutamente, não!" ${ }^{\prime}$. E complementa com o que segue: "as leis ordinárias encontram seu fundamento e validade, seu ser, no próprio Texto Constitucional, tal qual as leis complementares encontram seu engate lógico na Constituição. Portanto, não há hierarquia entre a lei complementar e a lei ordinária"66.

Ora, a norma que determina o modo de produção das leis ordinárias e das leis complementares é a Constituição da República, podendose inferir daí que realmente é a Carta Maior que dá a ambas o fundamento de validade e que, por conseguinte, a lei ordinária e a lei complementar não fundam a validade uma da outra, estando, portanto, em relação de coordenação, e não de subordinação hierárquica.

Mesmo os distintos campos materiais de incidência das leis complementar e ordinária, reconhecidos por Temer ${ }^{67}$, reforçam tal relação de coordenação entre as duas espécies normativas, cujas consequências serão examinadas em seguida.

Destarte, da posição topográfica da lei complementar no art. 59, II, da Constituição de República, outra conclusão não se pode extrair senão a de que a lei complementar é espécie normativa autônoma, distinta, portanto, da lei ordinária, mas não necessariamente superior ou inferior a ela.

Ademais, a se considerar a lei complementar espécie normativa de hierarquia superior à lei ordinária por antecedê-la no rol do art. 59 da

\footnotetext{
${ }^{64}$ BORGES, Souto Maior. Eficácia e Hierarquia da Lei Complementar. In Revista de Direito Público. no 25. São Paulo: RT, 1973. p. 95.

${ }^{65}$ TEMER, Michel. Elementos de Direito Constitucional. p. 146.

${ }^{66}$ Idem, p. 147.

${ }^{67}$ Idem, p. 148.
} 
Constituição de 1988, seria razoável concluir que imediatamente abaixo das leis ordinárias se posicionam as leis delegadas (inciso IV), e subordinadas a estas as medidas provisórias (inciso $\mathrm{V}$ ), seguidas pelos decretos legislativos (inciso VI) e estes pelas resoluções (inciso VII).

Assim não ocorre, porém.

Montoro, ao discorrer sobre as espécies normativas na Constituição, assevera que "ao lado das leis ordinárias, a Constituição menciona, nos diferentes itens do art. 59: - as leis delegadas; -. as medidas provisórias; - os decretos legislativos; - as resoluções. Tais normas têm a mesma hierarquia das leis ordinárias" 68 .

Bastos compartilha de tal compreensão:

A só circunstância da lei complementar ser mencionada antes da ordinária, no art. 46 do Texto Supremo [Emenda Constitucional $n^{\circ}$ 01/1969] nada significa em termos de posicionamento hierárquico. Se o raciocínio fosse bom, então, pelo mesmo motivo, também a lei ordinária estaria acima do decreto-lei, da lei delegada e assim por diante. Na verdade, a lei ordinária e a lei complementar não se subordinam reciprocamente (o que se verifica, por exemplo, entre a lei e o regulamento), porquanto versam matérias distintas e buscam seus fundamentos de validade diretamente na Constituição ${ }^{69}$.

Moraes recorda que "todas as espécies normativas primárias retiram seu fundamento de validade da própria Constituição Federal, inclusive as próprias Emendas Constitucionais, e nem por isso se diga que estariam no mesmo patamar hierárquico que as demais"70.

De fato, quanto à posição hierárquica da emenda à Constituição, prevista no inciso I do art. 59 da Carta Magna de 1988, não houve dissenso doutrinário: aquela espécie normativa ocupa o primeiro plano na hierarquia jurídica ${ }^{71}$, se sobrepondo tanto à lei complementar quanto à lei ordinária e às demais espécies normativas elencadas no dispositivo mencionado.

\footnotetext{
${ }^{68}$ MONTORO, Franco. Introdução à Ciência do Direito. $22^{\mathrm{a}}$ ed. São Paulo: RT, 1994. p. 337.

${ }^{69}$ BASTOS, Celso Ribeiro. Lei Complementar. Teoria e Comentários. p. 24.

${ }^{70}$ MORAES, Alexandre de. Direito Constitucional. p. 699.

${ }^{71}$ MONTORO, Franco. Op. cit. p. 335.
} 
Ocorre que a Emenda Constitucional não está no mesmo patamar das demais espécies normativas primárias porque, quando editada, passa a integrar o texto da Constituição e a se revestir, portanto, da qualidade de norma constitucional. Ora, desde que encartada no texto da Carta Magna, não há possibilidade de atribuir à Emenda Constitucional patamar inferior ou igual às demais espécies normativas, pois isso equivaleria a atribuir à própria Constituição tal característica. As demais espécies normativas, ao contrário, não integram a Constituição, apenas a complementam, em sentido material, já delineado. É somente por força desta distinção substancial, e não por outros critérios, que se aponta a superior hierarquia da Emenda à Constituição em face das outras espécies de normas do art. 59, motivo pelo qual não se pode estender o patamar hierárquico daquela para estas, importando ainda recordar que, tal como as demais espécies normativas, a Emenda Constitucional também se sujeita ao controle de constitucionalidade.

Conforme Leal, "a designação leis complementares não envolve, porém, como é intuitivo, nenhuma hierarquia do ponto de vista da eficácia em relação às outras leis declaradas não complementares. Todas as leis, complementares ou não, têm a mesma eficácia jurídica, e umas e outras se interpretam segundo as mesmas regras destinadas a resolver conflitos de leis no tempo" 72 .

Em resumo, não é a lei complementar que determina a elaboração da lei ordinária, vale dizer, que lhe confere fundamento, mas sim a Constituição, mesmo diploma normativo que define (ainda que por exclusão) seu conteúdo, de modo que não há como sustentar a existência de hierarquia entre as duas espécies legais aqui examinadas.

Já no que toca à característica do quorum qualificado para aprovação da lei complementar, importa considerar que a Constituição determina o órgão (Congresso Nacional, na Constituição da República, e Assembléia Legislativa, na Constituição do Estado) e o quorum (maioria absoluta, qualificada) pelos quais se há de produzi-la e, à vista de tal disposição, diz a doutrina, sem maiores indagações, que aquela espécie normativa teria superioridade formal e eficacial sobre a lei ordinária ${ }^{73}$.

Contudo, Bastos afirma que "a exigência de quorum especial de votação para as leis complementares [...] não implica em hierarquia entre

\footnotetext{
${ }^{72}$ LEAL, Vítor Nunes. Leis Complementares da Constituição. In Revista de Direito Administrativo, VII, p. 382.

${ }^{73}$ BORGES, José Souto Maior. Lei Complementar Tributária, p. 44.
} 
a lei ordinária e a complementar"74, o que se dá até porque todo e qualquer ato normativo tem um procedimento próprio de elaboração, mais ou menos dificultoso.

Ademais, como ensina Borges ${ }^{75}$, a eficácia pressupõe a existência da lei, e o quorum qualificado do art. 69 da vigente Constituição da República é, na verdade, requisito de existência, e não de eficácia da lei complementar. Assim, sem o referido quorum, que é apenas requisito procedimental de criação da norma, não existe lei complementar em sentido formal, independentemente de qualquer consideração sobre sua eficácia, que deve ser examinada em plano diverso.

O quorum especial para aprovação é pertinente, portanto, apenas à existência e à validade da norma, não conferindo à lei complementar maior eficácia ou maior hierarquia que a da lei ordinária, de modo que, na ausência do quorum qualificado, aquela espécie de lei não chegará a existir enquanto tal ${ }^{76}$.

Aliás, não é de se admitir que por exigir quorum diferenciado em sua tramitação o ato legislativo se revista de eficácia diferenciada também porque isso seria transpor indevidamente o plano da existência para o plano da eficácia da lei ${ }^{77}$.

Ademais, o quorum diz respeito apenas à rigidez relativa da norma, caracterizada pela maior dificuldade existente para sua criação e alteração, derivada da representatividade qualificada exigida para $\operatorname{tal}^{78}$. Tal elemento é irrelevante para o exame da maior ou menor eficácia ou hierarquia da lei complementar ${ }^{79}$ e deriva de opção política do poder constituinte originário, que decidiu aquilatar a representatividade necessária para aprovar atos legislativos versantes sobre determinadas matérias ${ }^{80}$.

Ferreira Filho acrescenta que "a lei complementar só pode ser aprovada por maioria qualificada, a maioria absoluta, para que não seja, nunca, vontade de uma minoria ocasionalmente em condições de fazer prevalecer sua voz" $"$.

\footnotetext{
${ }^{74}$ BASTOS, Celso Ribeiro. Lei Complementar. Teoria e Comentários, p. 25.

${ }^{75}$ BORGES, José Souto Maior. Lei Complementar Tributária, p. 45.

${ }^{76}$ Idem, p. 46.

${ }^{77}$ Idem, p. 47.

${ }^{78}$ Idem, p. 48.

${ }^{79}$ Idem, p. 49.

${ }^{80}$ Idem, p. 50.

${ }^{81}$ FERREIRA FILHO, Manoel Gonçalves. Lei Complementar - II. In Enciclopédia Saraiva de Direito. p. 513 .
} 
Segundo Temer, a distinção entre lei ordinária e complementar repousa também sobre o quorum especial exigido para a aprovação desta última, mas tal particularidade, contudo, não leva à conclusão de que exista hierarquia entre as duas espécies normativas ${ }^{82}$.

Esses, em suma, os posicionamentos doutrinários que se inclinam pela inexistência de hierarquia entre lei complementar e lei ordinária.

\subsection{A HIERARQUIA SEGUNDO A ESPÉCIE DE LEI COMPLEMENTAR}

Além da afirmação e da negação da superioridade hierárquica das leis complementares sobre as leis ordinárias, sem qualquer distinção das espécies de leis complementares, há entendimento que considera possível ou não a superioridade em referência, conforme a característica de que se revista determinada lei complementar.

Segundo Carvalho, foi José Souto Maior Borges quem demonstrou que as leis complementares não possuem fisionomia unitária que lhes confira, de plano, superioridade hierárquica no sistema jurídico e, em decorrência disso, classificou as leis complementares em duas espécies: aquelas que fundamentam a validade de outros atos normativos e as que não fundamentam a validade de tais atos, ou seja, que cumprem sua finalidade constitucional independentemente da edição de outras normas ${ }^{83}$.

Assim leciona Carvalho:

Em alguns casos a lei complementar subordina a lei ordinária, enquanto noutros descabem considerações de supremacia nos níveis do ordenamento, urna vez que tanto as leis complementares quanto as leis ordinárias extratam seu conteúdo diretamente do texto constitucional ${ }^{84}$.

Colhe-se da doutrina de Silva:

Se as [leis complementares] do primeiro grupo fundamentam a validade de outros atos normativos, isso

\footnotetext{
${ }^{82}$ TEMER, Michel. Elementos de Direito Constitucional. p. 148.

${ }^{83}$ CARVALHO, Paulo de Barros. Curso de Direito Tributário. p. 206.

${ }^{84}$ Idem, p. 206.
} 
indica relação hierárquica, de tal sorte que tais atos hão que conformar-se a seu fundamento de validade [lei complementar], que, por isso, se coloca em nível superior. Não são desse tipo as leis complementares que estatuem sobre situação concreta, as do segundo grupo [que não fundamentam a validade de outros atos normativos], porque resolvem a questão individualizadamente, 'em campo privativo'85.

Destarte, embora tratadas de modo uniforme pela Constituição da República (art. 59, II, c/c art. 69), as leis complementares não constituem categoria unitária, em razão da distinção acima apontada ${ }^{86}$.

Acrescenta Borges que as leis complementares que fundamentam a validade de outros atos normativos não o fazem apenas quanto às leis ordinárias estaduais e municipais, mas também em face das leis ordinárias da União, o que reforça a isonomia das pessoas políticas, assentada na Constituição da República ${ }^{87}$.

Já Bastos classifica as leis complementares em exaurientes e continuáveis $^{88}$. Aquelas "consumam, em si mesmas, os fins práticos a que se preordenam [...] veiculam medidas de per si produtoras de efeitos, sem qualquer adjutório de outra espécie normativa"89. Estas, ao inverso, são passíveis "de um prosseguimento de sua normatividade por via de lei ordinária" 90 .

Em síntese, tais são os três posicionamentos doutrinários existentes sobre o problema da hierarquia da lei complementar em face da lei ordinária.

\section{LEIS COMPLEMENTARES E LEI ORDINÁRIAS: PROBLEMA DA REVOGAÇÃO}

Passa-se agora ao exame da possibilidade de revogação da lei complementar pela lei ordinária. O problema inverso, qual seja, da revo-

\footnotetext{
${ }^{85}$ SILVA, José Afonso da. Aplicabilidade das Normas Constitucionais. p. 247.

${ }^{86}$ BORGES, José Souto Maior. Lei Complementar Tributária. p. 84.

${ }^{87}$ Idem, p. 83.

${ }^{88}$ BASTOS, Celso Ribeiro. Lei Complementar. Teoria e Comentários. p. 35.

${ }^{89}$ Idem, p. 35

${ }^{90}$ Idem, p. 37.
} 
gação da lei ordinária pela lei complementar, será apenas superficialmente abordado, por não ter produzido, em doutrina, controvérsia significativa.

O ponto ora examinado é derivado do apreciado anteriormente. Em outras palavras, as distintas soluções apontadas para o questionamento afeto à possibilidade de revogação da lei complementar pela lei ordinária são influenciadas pelo acolhimento de uma ou outra das posições referentes à existência ou inexistência de hierarquia entre essas duas espécies normativas.

Como visto, a doutrina reconhece a existência de campos materiais distintos e reciprocamente excludentes para a lei complementar e a lei ordinária. À lei complementar fica reservado o regramento das matérias expressamente previstas na Constituição, e à lei ordinária cabe reger as matérias restantes (competência material residual).

Assim, à vista da diversidade de matérias cometidas à lei complementar e à lei ordinária, da invasão do campo temático específico daquela por esta advém consequências jurídicas, bem assim da invasão pela lei complementar do campo material reservado à lei ordinária.

Para a doutrina, lei complementar que verse sobre matéria de lei ordinária, exorbitando seu campo temático específico, tem plena validade, mas como simples lei ordinária, ainda que se lhe dê nome de lei complementar, podendo, assim, uma lei ordinária revogá-la.

É o que sustenta Ferreira:

A lei complementar pode invadir a esfera da lei ordinária, não podendo porém disciplinar a matéria própria do decreto legislativo e da resolução. (...) Se a lei complementar extravasar a matéria específica do seu campo, delimitado em numerus clausus pelo legislador constituinte, tem a norma evidentemente validade, mas neste caso pode ser derrogada por norma ordinária, não havendo necessidade de norma complementar para o dito fim. Editada fora do seu campo especifico, ainda que se lhe dê o nome de lei complementar, a lei assim editada é apenas e nada mais que lei ordinária ${ }^{91}$.

Isso ocorre, segundo o autor, pela seguinte razão:

\footnotetext{
${ }^{91}$ FERREIRA, Luiz Pinto. Lei Complementar - I. In Enciclopédia Saraiva de Direito. p. 499.
} 
A Constituição Federal vigente fixou de modo exaustivo, em numerus clausus, o campo específico da lei complementar (...) fora desse campo específico, a lei editada não é lei complementar, e, consequentemente, não está dotada de nenhuma superioridade jurídica sobre a lei ordinária, mas ao contrário se nivela com esta ${ }^{92}$.

Desse entendimento não dissente Borges:

Se a lei complementar invadir o âmbito material de validade da legislação ordinária da União, valerá tanto quanto uma lei ordinária federal. Sobre esse ponto não há discrepância doutrinária. A lei complementar fora de seu campo específico, cujos limites estão fixados na Constituição, é simples lei ordinária ${ }^{93}$.

Assim, lei complementar fora de seu campo material é válida, mas como se lei ordinária fosse, sendo admissível, portanto, que outra lei ordinária a revogue.

Quanto à hipótese inversa, qual seja, de invasão do campo da lei complementar pela lei ordinária, sustenta Ferreira que "a lei ordinária não pode [...] revogar a lei complementar, sendo evidentemente nula toda lei ordinária na parte dela que contrasta com a lei complementar"94, o que ocorre pelos motivos que Silva expõe:

A lei ordinária que ofenda uma lei complementar estará vulnerando a própria Constituição, visto que disciplinará interesses que esta determina sejam regulados por ela. Tratar-se-á, então, de conflito de norma, subordinado ao princípio da compatibilidade vertical, entroncando, pois, na norma de maior superioridade hierárquica, que é a que ficou ofendida - a Constituição. Pronunciamo-nos, destarte, pelo controle de constitucionalidade das leis, com todas as

\footnotetext{
${ }^{92}$ FERREIRA, Luiz Pinto. Lei Complementar - I. In Enciclopédia Saraiva de Direito. p. 499

${ }^{93}$ BORGES, José Souto Maior. Lei Complementar Tributária. p. 26.

${ }^{94}$ FERREIRA, Luiz Pinto. Op. cit., p. 497.
} 
suas consequências, quando uma regra jurídica ordinária conflite com uma complementar ${ }^{95}$.

Segundo Borges, se "a lei ordinária da União invadir o campo da lei complementar estará eivada de visceral inconstitucionalidade porque a matéria, no tocante ao processo legislativo, somente poderia ser apreciada com observância de um quorum especial e qualificado, inexistente na aprovação da lei ordinária"96.

E para Ataliba, "toda vez, pois, que se trate de matéria para a qual a Constituição exija expressamente disciplina por lei complementar, só este tipo de norma - reconhecível formalmente por seu processo de elaboração - pode preencher a exigência constitucional. Daí ser nula, inexistente, de nenhum efeito, a norma ordinária versando matéria para cuja disciplina se requeira lei complementar. A fortiori, toda e qualquer outra norma que tenha a pretensão de invadir esta seara deve ser reputada inexistente. Não tem, efetivamente, condição de ingresso à ordem jurídica ou força para alterar o sistema, as leis ordinárias, delegadas, decretos-leis, decretos legislativos ou resoluções, quando se cuide de ordenar matéria inserida neste campo"97.

Bacha resume as duas hipóteses:

Se uma lei complementar invade área de ação em matéria reservada à lei ordinária, será considerada uma lei ordinária; mas, se uma lei ordinária invade área de ação em matéria reservada à lei complementar, será considerada inconstitucional. Quer dizer, ocorrendo a primeira hipótese, a lei complementar se verá transformada numa lei ordinária; ocorrendo a segunda hipótese, a lei ordinária será fulminada com o decreto fatal de inconstitucionalidade ${ }^{98}$.

Assim, não se tem admitido em doutrina que a lei ordinária contraste com a lei complementar ou a revogue, sob pena de nulidade (Luiz Pinto Ferreira), inconstitucionalidade (José Afonso da Silva, José Souto

\footnotetext{
${ }^{95}$ SILVA, José Afonso da. Aplicabilidade das Normas Constitucionais. p. 248.

${ }^{96}$ BORGES, José Souto Maior. Lei Complementar Tributária. p 27.

${ }^{97}$ ATALIBA, Geraldo. Lei Complementar na Constituição. p. 34.

${ }^{98}$ BACHA, Sergio Reginaldo. Constituição Federal. Leis Complementares e Leis Ordinárias. Hierarquia? p. 112.
} 
Maior Borges e Sérgio Reginaldo Bacha) ou inexistência e ineficácia (Geraldo Ataliba).

No que tange à orientação do Supremo Tribunal Federal acerca da matéria, veja-se a síntese de Paulo e Alexandrino:

A tese que prevaleceu na jurisprudência do STF foi a da não existência de hierarquia entre lei complementar e lei ordinária. Para o Tribunal, a distinção entre elas deve ser aferida em face da Constituição, considerando o campo de atuação de cada uma.

Assim, entende a nossa Corte Constitucional que a lei complementar só possui tal natureza quando disciplina matéria especificamente reservada na Constituição a essa espécie normativa. Somente a partir da matéria indicada em dispositivo constitucional como reservada é que se identifica uma lei complementar. Corolário desse entendimento são as seguintes orientações emanadas do Supremo Tribunal Federal:

a) não há hierarquia entre lei complementar e lei ordinária, mas sim campos específicos de atuação de cada uma dessas espécies normativas;

b) só a lei complementar material aquela aprovada por maioria absoluta pelas Casas do Congresso Nacional e que trate de matéria reservada pela Constituição para esse tipo de lei;

c) lei ordinária, lei delegada e medida provisória não podem regular matéria reservada pela Constituição à lei complementar, sob pena de incorrerem em vício de inconstitucionalidade formal;

d) lei complementar pode tratar de matéria ordinária, sem incorrer em vício de inconstitucionalidade formal, mas, nesse caso, tal lei será apenas formalmente complementar (será materialmente ordinária), isto é, o conteúdo dessa lei permanecerá com status ordinário. Logo, poderá ser posteriormente modificada ou revogada por lei ordinária99.

Assim, a lei complementar é tema contingente, que tem raízes no Direito Positivo e deve ser entendido à luz do sistema jurídico que a

\footnotetext{
${ }^{99}$ PAULO, Vicente; ALEXANDRINO, Marcelo. Processo Legislativo. p. 198/199.
} 
previu $^{100}$, sendo os acima expostos seus traços fundamentais no Direito Positivo brasileiro, notadamente quanto aos problemas da hierarquia e revogação em face da lei ordinária.

\section{CONSIDERAÇÕES FINAIS}

Ao final deste estudo tem-se que:

a) a lei complementar tem acepção formal (expressamente prevista na Constituição, sujeita à aprovação por maioria absoluta) e material (toda a que completa o texto da Constituição);

b) a lei ordinária é a espécie normativa padrão, típica, geral e abstrata, aprovada por maioria simples, com campo material definido pelo critério residual;

c) os que sustentam existir relação de hierarquia entre lei complementar e lei ordinária atribuem superioridade àquela porque se abaixo da emenda constitucional e acima da lei ordinária no art. 59 da Constituição e porque tem quorum qualificado para aprovação;

d) os que sustentam inexistir aquela relação de hierarquia argumentam que a lei complementar, como a ordinária, retira seu fundamento de validade da Constituição, que determina o modo de produção de ambas, e que o quorum qualificado é requisito de existência e não de eficácia da lei complementar;

e) os que sustentam que a relação de hierarquia depende da espécie de lei complementar considerada entendem haver leis complementares que fundamentam a validade de outros atos normativos e que não fundamentam a validade desses atos, ou seja, que cumprem sua finalidade constitucional independentemente da edição de outras normas, sendo aquelas, mas não estas, superiores às leis ordinárias;

f) quanto à possibilidade de revogação, a lei complementar, fora de seu campo específico, fixado na Constituição, é simples lei ordinária, podendo por ela ser revogada; ao inverso, a lei ordinária fora de seu campo específico não se toma lei complementar (não observa quorum qualificado e campo material) nem a revoga, sendo inconstitucional;

${ }^{100}$ BASTOS, Celso Ribeiro. Lei Complementar. Teoria e Comentários. $2^{\mathrm{a}}$ ed, p. 41. 
g) o STJ tem considerado que, em face de sua superioridade hierárquica, a lei complementar não pode ser revogada pela lei ordinária; parte de seus julgados vê no conflito entre lei ordinária e lei complementar matéria infraconstitucional, apreciável pelo STJ, e outra parte sustenta que o confronto é constitucional, de competência do STF;

i) parte da jurisprudência do STF reconheceu a superioridade hierárquica da lei complementar sobre a lei ordinária e a impossibilidade de revogação daquela espécie legal por esta; outra parte decidiu o inverso; o STF entendeu, ademais, que a lei complementar só é exigível nos casos expressamente previstos na Constituição, admitindo-se a edição de lei ordinária nas hipóteses restantes.

\section{REFERÊNCIAS BIBLIOGRÁFICAS}

ARAÚJO, Luiz Alberto David; NUNES JR. Vidal Serrano. Curso de Direito Constitucional. São Paulo: Saraiva, 1998.

ATALIBA, Geraldo. Lei Complementar na Constituição. São Paulo: RT, 1971.

BACHA, Sergio Reginaldo. Constituição Federal: Leis Complementares e Leis Ordinárias. Hierarquia? Belo Horizonte: Fórum, 2004.

BASTOS, Celso Ribeiro. Do Processo Legislativo da Lei Complementar. In Revista de Direito Constitucional e Internacional, $n^{\circ}$ 38. São Paulo: RT, 2002.

. Lei Complementar. Teoria e Comentários. $2^{\mathrm{a}}$ ed. São Paulo: Celso Bastos Editor: Instituto Brasileiro de Direito Constitucional, 1999.

Lei Complementar. Teoria e Comentários. São Paulo: Saraiva, 1985.

BORGES, José Souto Maior. Lei Complementar Tributária. São Paulo: RT: EDUC, 1975.

. Eficácia e Hierarquia da Lei Complementar. In Revista de Direito Público n ${ }^{\circ}$ 25. São Paulo: RT, 1973.

BRASIL. Constituição da República Federativa do Brasil, de 05 de outubro de 1988. In: Códigos Penal, Processo Penal, Constituição Federal e legislação complementar. $8^{\text {a }}$ ed. São Paulo: Saraiva, 2012.

CAMPANHOLE, Adriano; CAMPANHOLE, Hilton Lobo. Constituições do Brasil. 10ª ed. São Paulo: Atlas, 1992.

CARVALHO, Paulo de Barros. Curso de Direito Tributário. 16 ed. São Paulo: Saraiva, 2004.

CLÈVE, Clemerson Merlin (coord.). Direito Constitucional Brasileiro. Vol. 2. Organização do Estado e dos Poderes. São Paulo: RT, 2014.

CRETELLA JR., José. Elementos de Direito Constitucional. $3^{\mathrm{a}}$ ed. São Paulo: RT, 2000. 
FERREIRA, Luiz Pinto. Lei Complementar - I. In: Enciclopédia Saraiva de Direito, v. 48. São Paulo: Saraiva, 1980.

FERREIRA FILHO, Manoel Gonçalves. Lei Complementar - II. In: Enciclopédia Saraiva de Direito, v. 48. São Paulo: Saraiva, 1980.

GUERRA, Sidney. MERÇON, Gustavo. Direito Constitucional Aplicado à Função Legislativa. Rio de Janeiro: América Jurídica, 2002.

KELSEN, Hans. Teoria Pura do Direito. $6^{\mathrm{a}}$ ed. Tradução de João Baptista dos Santos. São Paulo. Martins Fontes, 1998.

LEAL, Vítor Nunes. Leis Complementares da Constituição. In: Revista de Direito Administrativo. Vol. VII. Rio de Janeiro: Forense, 1947.

MACHADO, Hugo de Brito. Curso de Direito Tributário. 19a ed. São Paulo: Malheiros, 2001.

MALUF, Sahid. Direito Constitucional. 19ª ed. São Paulo: Sugestões Literárias, 1988.

MONTORO, Franco. Introdução à Ciência do Direito. $22^{\mathrm{a}}$ ed. São Paulo: RT, 1994.

MORAES, Alexandre de. Direito Constitucional. $28^{\mathrm{a}}$ ed. São Paulo: Saraiva, 2012.

PAULO, Vicente; ALEXANDRINO, Marcelo. Processo Legislativo. Niterói: Impetus, 2003.

SILVA, José Afonso da. Aplicabilidade das Normas Constitucionais. $3^{a}$ ed. São Paulo: Malheiros, 1998.

TEMER, Michel. Elementos de Direito Constitucional. 15 a ed. São Paulo: Malheiros, 1999. 